\section{Environmental effect on the leaf morphology and anatomy of Berberis microphylla G. Forst}

\author{
Silvia Radice, ${ }^{1}$ Miriam E. Arena ${ }^{2}$ \\ ${ }^{1}$ Laboratorio de Fisiología Vegetal, CON- \\ ICET-Facultad de Agronomía y Ciencias \\ Agroalimentarias, Universidad de Morón, \\ Buenos Aires; ${ }^{2}$ Laboratorio de Recursos \\ Agroforestales, Centro Austral de \\ Investigaciones Científicas, Ushuaia, \\ Argentina
}

\section{Abstract}

Berberis microphylla G. Forst is a fruit shrub native from Patagonia, considered as a non-timber forest product. In recent years, there has been an increased demand for its fruits, both for fresh and industrialized consumption, being the establishment of commercial orchards in different sites a need to meet this demand. B. microphylla cloned plants have been introduced from Ushuaia, Tierra del Fuego to Buenos Aires province in order to evaluate its phenotypic plasticity and the possibility of fruit production. At the same time, a comparative study on the morphology and anatomy of the mature leaves of $B$. microphylla grown in two different environmental conditions was carried out. Moreno leaves were significantly larger than Ushuaia leaves in all the morphological parameters registered, while Ushuaia leaves were more circular than Moreno leaves with the highest roundness and elongation indexes. Nevertheless, histological sections showed that Ushuaia leaves have one more layer of palisade cells respect to Moreno leaves. Ushuaia leaves showed higher palisade cells, larger abaxial epidermal cells and thicker cuticles than Moreno leaves. The stomatal density was superior on Moreno leaves. Scanning Electron Microscope of abaxial epidermis showed a surface with numerous ridges of different forms that prevent the layout of epidermal cells on Moreno leaves. Appearance of this surface is glossy and oily. On the contrary, epidermal cells are well recognized on Ushuaia leaves. Stomata of anomocytic type were observed and surface looks waxy. Auto-fluorescence on leaf cross sections were observed on the vascular bundles and partially on the epidermis cells. $B$. microphylla leaves showed a high phenotypic plasticity between the two sites of cultivation. The changes in the leaf morphology and structure observed in Moreno leaves could indicate that the plants are trying to adjust its morphology to the new culture conditions i.e. higher temperatures and lower irradiance.

\section{Introduction}

Berberis microphylla G. Forst (in the past Berberis buxifolia Lam.) is an evergreen shrub that may be semi-evergreen where winters are particularly cold and harsh, as it occurs in Tierra del Fuego. It is a spiny and erect shrub up to $4 \mathrm{~m}$ high, often growing in the magellanic subpolar forest Eco region, ${ }^{1}$ in coastal scrub, Nothofagus forest margins and clearings, moister areas in grass steppes, and along streams and rivers. ${ }^{2}$ It is one of the understory species in timber quality and associated nontimber quality stands of Nothofagus forests in Tierra del Fuego ${ }^{3}$ being considered as a nontimber forest product. In recent years, there has been an increased demand for the fruits of these shrubs and particularly for B. microphyl$l a$, both for fresh consumption and for the production of various products such as candies and jellies, pulps for making ice cream, beverages without alcohol and they are used in cosmetic products too. Also, in B. microphylla as in most of the species of the genus are assigned medicinal properties due to the presence of the alkaloids called berberine and berbamine..$^{4-8}$ Moreover, phenolics like as anthocyanins in the fruits, ${ }^{9-13}$ in the leaves ${ }^{14}$ and in the roots ${ }^{15,16}$ were found, which give a medicinal and tinctorial application.

Floral biology, fruit development and quality, and the assessment of morphological variability were studied in natural populations of $B$. microphylla, ${ }^{12,17-20}$ as well as the phenological stages and the annual cycle of growth and development. ${ }^{21,22}$ However, nothing has been yet said about the leaf morphology and structure of $B$. microphylla. The leaf can be considered as a micro copy of the plant, ${ }^{23}$ and the variations of leaf morphology can reflect the plant capacity to acquire, use and conserve resources. Under abiotic stress, plants alter their physiology, morphology and development in response to environmental changes. ${ }^{24}$

Some studies have been performed in the genus Berberis on this subject. Arambarri et $a l .,^{25}$ studied the leaf anatomy of $B$. ruscifolia. Histological description related to the pharmacological property was noticed on $B$. aristata, $B$. lyceum and $B$. asiatica ${ }^{26,27}$ Other antecedents have given greater importance to the study of the leaf compounds produced for their therapeutics action. $14,28-32$

In the last two years, a plot of $B$. microphylla cloned plants has been introduced to the Buenos Aires province in order to carry out experimental studies, i.e. evaluate its phenotypic plasticity and the possibility of fruit production. These plants have shown a good vegetative growth; flower differentiation was observed but until now fruits have not been formed. Leaves are photosynthetic organs thus their shapes, sizes and structure are important
Correspondence: Miriam E. Arena, Laboratorio de Recursos Agroforestales, Centro Austral de Investigaciones Científicas (CADIC - CONICET), Bernardo Houssay 200, 9410 Ushuaia, Tierra del Fuego, Argentina.

Tel.: +54.2901.422310/4 - Fax: +54.2901 .430644 .

E-mail: arena@cadic-conicet.gob.ar

Key words: barberry, leaf morphology, leaf anatomy, auto-fluorescence.

Acknowledgments: the authors thank to Isabel Farías for her technical assistance. They would also thank Eng Agr Marta Alonso, Mr S.E. Agüero, A. 0. Medina and J. Peralta.

Contributions: the authors contributed equally.

Conflict of interest: the authors declare no conflict of interest.

Finding: This work received funds from CONICET (PIP 0263 y 0223).

Received for publication: 22 October 2015.

Revision received: 21 January 2015.

Accepted for publication: 21 January 2015.

This work is licensed under a Creative Commons Attribution NonCommercial 3.0 License (CC BYNC 3.0).

(C) Copyright S. Radic and M.E. Arena, 2015

Licensee PAGEPress srl, Italy

International Journal of Plant Biology 2015; 6:5677 doi:10.4081/pb.2015.5677

factors influencing the success of the plants. Therefore the aim of this work was to study the morphology and anatomy of the mature leaves of $B$. microphylla plants grown in two different environmental conditions, on the origin site where they grow spontaneously and in a site where it is interesting to introduce them.

\section{Materials and Methods}

\section{Plant material and growing condi-} tions

Berberis microphylla plants were obtained through clonal propagation from a natural population and cultivated in pots $(n=40)$ in the experimental field of the Centro Austral de Investigaciones Científicas, Ushuaia, Tierra del Fuego, Argentina (54 $48^{\prime}$ SL, $68^{\circ} 19^{\prime}$ WL, 30 $\mathrm{m}$ a.s.l) for five years. At the beginning of 2013 , twenty plants were taken to Moreno (Buenos Aires) and cultivated in the experimental field of the Faculty of Agriculture, University of Morón (34 39' SL, 58 47’ WL, 19 m a.s.l).

Moreno climate is temperate sub humid with $1200 \mathrm{~mm}$ rainfalls per year and extreme temperatures are 40 and $-1^{\circ} \mathrm{C}$. On the other hand, Ushuaia climate is classified as sub polar oceanic with mild temperatures, i.e. not 
Table 1. Berberis microphylla morphological characteristics and measures according to the cultivation site.

\begin{tabular}{|c|c|c|c|c|c|c|c|}
\hline Cultivation site & Area, $\mathrm{mm}^{2}$ & Perimeter, mm & Leaf length, mm & Middle fraction & $\begin{array}{l}\text { Leaf width, mm } \\
\text { Bottom fraction }\end{array}$ & Top fraction & Petiole length \\
\hline Moreno & $123.46^{\mathrm{a}}$ & $60.86^{a}$ & $23.66^{\mathrm{a}}$ & $9.63^{\mathrm{a}}$ & $7.92^{\mathrm{a}}$ & $8.32^{\mathrm{a}}$ & $3.18^{\mathrm{a}}$ \\
\hline Ushuaia & $46.64^{b}$ & $30.94^{b}$ & $12.06^{\mathrm{b}}$ & $5.73^{b}$ & $4.71^{\mathrm{b}}$ & $4.51^{\mathrm{b}}$ & $2.27^{\mathrm{b}}$ \\
\hline
\end{tabular}

Means in the same column followed by different letters are significantly different at $\mathrm{P} \leq 0.01$ (Tukey's test).

extreme and abundant rainfalls throughout the year like the English weather and the extreme temperatures are 15 and $-5^{\circ} \mathrm{C}$. Climatic data were collected for mean, maxima and minima air daily temperatures $\left({ }^{\circ} \mathrm{C}\right)$, and rainfall $(\mathrm{mm})$ by the Meteorological Station located at the Centro Austral de Investigaciones Científicas, and the Meteorological Station located at the Moreno experimental field, from January 2013 to February 2014 (Figure 1).

\section{Leaf morphology and anatomy}

One year after their establishment (February 2014), mature leaves $(n=20)$ were taken from the plants of the two sites of culture and immediately they were scanned. The leaf area, leaf perimeter, leaf major and minor axis were registered. Then, the index of elongation (leaf major axis/leaf minor axis), roundness [ $(4 \times \pi \times$ area $) /$ perimeter $\left.^{2}\right]$ and compactness [sqrt $(4 \times$ area $/ \pi) /$ major axis length] were calculated. Then, the leaves were fixed on FAA solution. Some of them were employed for histological section using Spurr's resin technique and the others were studied by SEM (Scanning Electron Microscope).

Light microscopy: leaves were dehydrated in an ethanol series and embedded in Spurr's resin. Thin sections (75-90 $\mathrm{nm}$ thick) were stained with uranyl acetate and lead citrate. Histological sections were used to study the mesophyll structure. Cells of each tissue were measured in height and width and the volume was calculated. Leaf cross sections without stain were observed by UV filter BP 340-380.

Scanning electron microscopy: leaves were dehydrated in an ethanol series and critical point drying technique was employed. Samples were sputter coated with $20 \mathrm{~nm}$ gold and observed with a SEM (Philips XL-30; Philips, Amsterdam, The Netherlands). Stomata of abaxial epidermis were measured and then density (stomata number $/ \mathrm{mm}^{2}$ ) was calculated.

\section{Results}

\section{Leaf morphology}

Berberis microphylla leaf morphology was significantly different between the cultivation sites. In effect, Moreno leaves were signifi-

Table 2. Elongation, roundness and compactness indexes of $B$. microphylla leaf according to the cultivation site.

\begin{tabular}{lccc} 
Cultivation site & Elongation & Roundness & Compactness \\
Moreno & $0.43^{\mathrm{b}}$ & $0.43^{\mathrm{b}}$ & $0.54^{\mathrm{b}}$ \\
Ushuaia & $0.48^{\mathrm{a}}$ & $0.61^{\mathrm{a}}$ & $0.64^{\mathrm{a}}$ \\
\hline
\end{tabular}

Means in the same column followed by different letters are significantly different at $\mathrm{P} \leq 0.01$ (Tukey's test).

cantly larger than Ushuaia leaves in all the parameters registered (Table 1). Leaf length, leaf width and leaf perimeter of Moreno site were about twice than those of Ushuaia leaves, while leaf area was three times higher than Ushuaia leaves. Petiole length of Moreno leaves was significantly larger than Ushuaia leaves too (Table 1). Conversely, values of index calculated were higher for Ushuaia leaves (Table 2). Ushuaia leaves were more circular than Moreno leaves with the highest roundness and elongation indexes.

\section{Light microscopy}

Leaves of $B$. microphylla are exhibited dorsiventrality. Leaves are formed by a mesophyll differentiated into a palisade and a spongy mesophyll. Palisade cells are arranged on the adaxial surface. Cells of the palisade are elongated in the transverse plane of the leaf, with many chloroplasts (Figure 2A,B) and they are densely packed together into two layers on Moreno leaves (Figure 2A) and into three layers on Ushuaia leaves (Figure 2B). Sclerenchyma cells are present in adaxial sub epidermical position only on Ushuaia leaves (Figure 2B). The spongy mesophyll is present with irregular branching cells containing chloroplasts and separated by large air spaces. The spongy mesophyll is arranged on the abaxial side (Figure 2A,B,G,H). Vascular bundles which are part of the venation can be observed into the mesophyll. Phloem and xylem tissues are in abaxial and adaxial positions, respectively (Figure 2A). Parenchyma cells and some sclerenchyma cells are present surrounded the vascular bundle on Ushuaia leaves (Figure 2B). Nevertheless, parenchyma cells dominate Moreno leaves. Auto-fluorescence on leaf cross sections was observed. In effect, on the vascular bundles there was possible to detect cells with fluorescence (Figure 3A,B). Some parts of the epidermis present fluorescence too (Figure 3C). This confirms that there are laticifer-idioblast cells.
All the mesophyll is surrounded by the epidermis and cover by the cuticle (Figure 2E,F,I,J). The adaxial epidermis has larger cells than abaxial epidermis (Figure 2C-F). No significant differences were observed between the cell measures of adaxial epidermis of the two cultivation sites (Table 3). However, the height and volume of the abaxial epidermis cells and the cuticle was larger on the Ushuaia leaves. In effect, the cuticle of Moreno leaves were $2 \mu \mathrm{m}$ wide while Ushuaia leaves were 5-6 $\mu \mathrm{m}$ wide (Figure 2E,F). On the other hand, the same differences were observed on the abaxial epidermis. Cuticle of Ushuaia leaves were 2.5 - $3 \mu \mathrm{m}$ width, while Moreno leaves were 1-1.5 $\mu \mathrm{m}$ width, (Figure 2I,J). The abaxial epidermis cells on Ushuaia leaves were significant higher than those of Moreno leaves (Table 3). Finally, Moreno leaves were thinner than Ushuaia leaves, being the leaf thickness of $350 \mu \mathrm{m}$ and $470 \mu \mathrm{m}$, respectively (Figure 2A,B).

\section{Scanning electron microscopy}

The abaxial epidermis appearance is different depending on the cultivation site. In effect, the leaves taken from Moreno site show an irregular surface due to the molecular architecture of the films of the epi-cuticle wax. The surface presents numerous ridges of different forms and closely placed near to the stomata that don't allow the differentiation of the arrangement of epidermal cells (Figure $3 \mathrm{E}, \mathrm{F})$.The appearance of this surface is glossy and oily. Numerous particles coating the surface of the guard cells flow from the stomatal pore (Figure 3G). On the other hand, epidermal cells are well recognized on abaxial epidermis from Ushuaia leaves (Figure $3 \mathrm{H}, \mathrm{I}$ ). Stomata of anomocytic type are observed, being the pair of guard cells surrounded by 5-6 unspecialized epidermal cells, and surface looks waxy (Figure 3G,I). Venation with its ramification is well recognized on diaphanized leaves (Figure 3K-M). Adaxial epidermal cell arrangement is isodiametric (Figure 3L) and 
the stomata surrounded by generic format of epidermal cells are noticed on the abaxial epidermis (Figure 3M). Stomatal density for leaves collected on Moreno site varied between 330 and 450 per $\mathrm{mm}^{2}$, while in leaves from Ushuaia site the values recorded were 210-330 stomata/mm² (data not shown).

\section{Discussion}

Leaves are important organs for photosynthesis and play a crucial role in survival and growth of a plant. The leaf can be considered as a microcopy of the plant, and the variations of leaf morphology can reflect the plant capacity to acquire, use and conserve resources. ${ }^{33}$ Leaf morphology like as specific leaf area changes with the plant growth conditions i.e. temperature. ${ }^{34}$ Light availability can modify leaf anatomy and therefore affect plant growth. ${ }^{35}$ Climatic conditions of the two selected sites for this study are quite different so it is expected to be one of the causes of morphological differences. Furthermore, many species have acquired plasticity for the leaf shape giving responses to changes in the environmental conditions. Plants were grown in Moreno site surrounded by trees to reduce high temperatures, so that the presence of neighboring vegetation could have modified the light environment. It has been demonstrated in Arabidopsis thaliana that changes in environmental light generate signals that are perceived by phytochromes and cryptochromes. ${ }^{36}$ In consequence, an elongation of the petiole and an increase of the leaf blade area is a typical example of leaf shape plasticity called shadeavoidance syndrome. Ushuaia leaves have a higher roundness and elongation indexes. A correlation between leaf roundness and irradiance was found in Nothofagus solandri, decreasing with increasing irradiance; however, a non-significant correlation was found in N. fusca. ${ }^{37}$

As well knows on others species, external changes in $B$. microphylla were reflected in an increase in the volume of each cell when a decrease in cell proliferation was observed as a compensation phenomenon. ${ }^{38}$ Another differ-
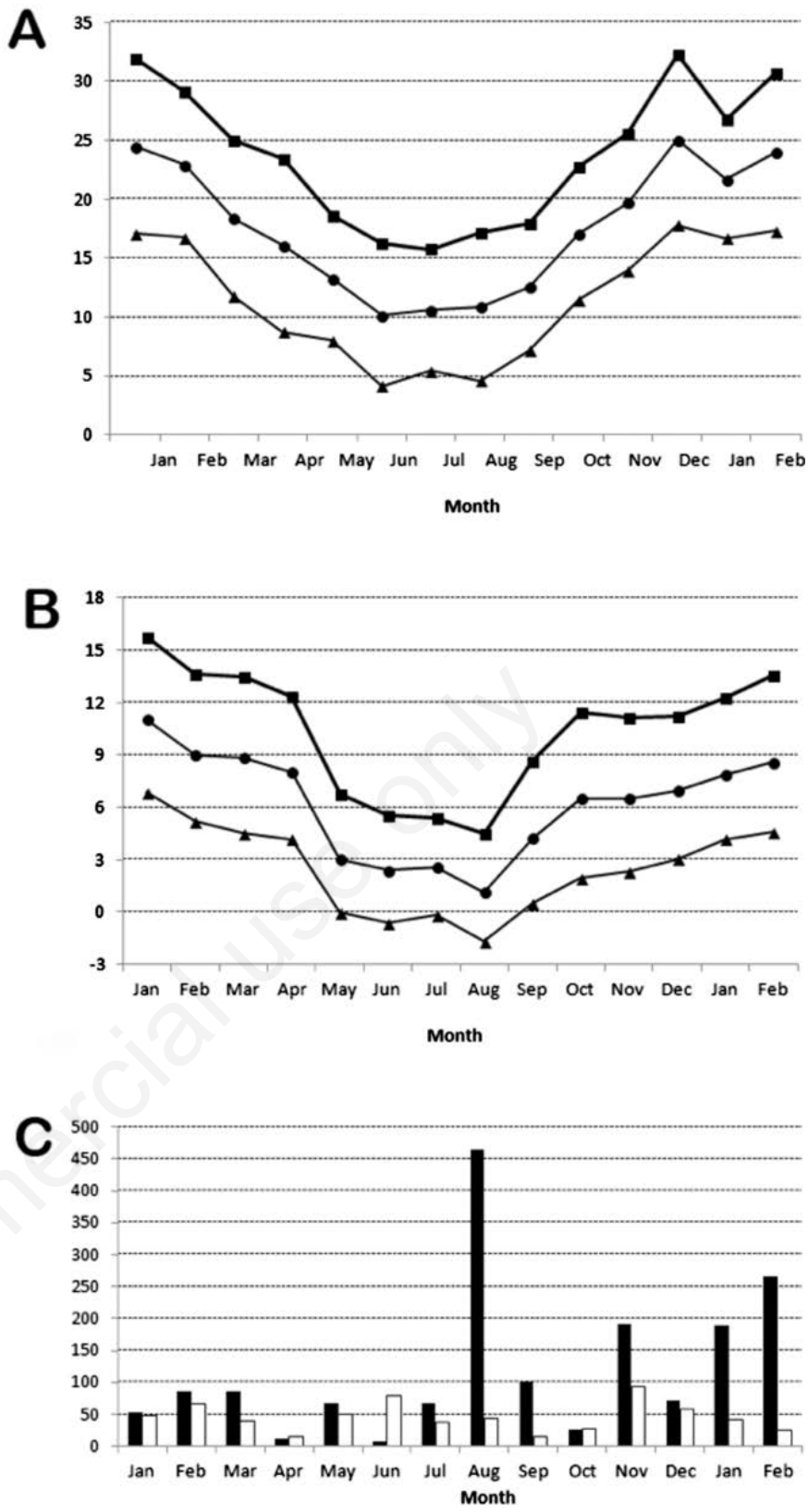

Figure 1. Temperature (A-B) and rainfall (C) registered by the Meteorological Station located at the Centro Austral de Investigaciones Científicas (Ushuaia, Tierra del Fuego, Argentina; B-C) and the Meteorological Station located at the Moreno experimental field (Buenos Aires, Argentina; A-C) from January 2013 to February 2014. A-B) Mean (circle), maxima (square) and minima (triangle) air daily temperatures $\left({ }^{\circ} \mathrm{C}\right)$; $\mathrm{C}$, rainfall $(\mathrm{mm})$, Moreno (black), Ushuaia (white).

Table 3. Berberis microphylla leaf cell measures studied by light microscopy according to the place of cultivation.

\begin{tabular}{|c|c|c|c|c|c|c|}
\hline \multirow[t]{2}{*}{ Tissue } & \multicolumn{2}{|c|}{ Height $\mu \mathrm{m}$} & \multicolumn{2}{|c|}{ Width jum } & \multicolumn{2}{|c|}{ Volume $\mathrm{um}^{3}$} \\
\hline & Moreno & Ushuaia & Moreno & Ushuaia & Moreno & Ushuaia \\
\hline Palisade cells & $47.33^{\mathrm{b}}$ & $72.17^{\mathrm{a}}$ & $19.10 \mathrm{a}$ & $19.80^{\mathrm{a}}$ & $912.00^{\mathrm{b}}$ & $1435.00^{\mathrm{a}}$ \\
\hline Spongy cells & $19.40^{\mathrm{a}}$ & $21.25^{\mathrm{a}}$ & $25.00 \mathrm{~b}$ & $30.35^{\mathrm{a}}$ & $512.00^{b}$ & $635.00^{\mathrm{a}}$ \\
\hline Adaxial epidermis cells & $19.04^{\mathrm{a}}$ & $18.5^{\mathrm{a}}$ & $38.50 \mathrm{a}$ & $37.80^{\mathrm{a}}$ & $746.15^{\mathrm{a}}$ & $702.50^{\mathrm{a}}$ \\
\hline Abaxial epidermis cells & $11.20^{\mathrm{b}}$ & $14.75^{\mathrm{a}}$ & $21.80 \mathrm{a}$ & $23.30^{\mathrm{a}}$ & $248.00^{b}$ & $340.00^{\mathrm{a}}$ \\
\hline Stomata & $3.24^{\mathrm{a}}$ & $2.10^{\mathrm{b}}$ & $3.53 \mathrm{a}$ & $2.07^{\mathrm{b}}$ & - & - \\
\hline
\end{tabular}

Means in the same line and for each variable followed by different letters are significantly different at $\mathrm{P} \leq 0.01$ (Tukey's test). 
ence found between these leaves was the thickness of the cuticle. The cuticle has two main components: cutin and waxes. Cutin is a tough, cross-linked polyester matrix primarily composed of $\mathrm{C} 16$ and $\mathrm{C} 18$ oxygenated fatty acids and glycerol. Wax is a heterogenous mixture, primarily composed of very-long-chain fatty acid derivatives. ${ }^{39}$ The cuticular wax in Berberis is crystalloid usually as clustered tubuli, chemically dominated by nonacosane10-ol. ${ }^{40}$ Little is known about how waxes are trafficked within the cell from their site of synthesis at the endoplasmatic reticulum to the plasma membrane. ${ }^{41}$ Many authors considered that wax extruded from epidermal cells. ${ }^{41-43}$ Epicuticular waxes are modified by changes in plant growth conditions such as temperature, relative humidity, irradiance, and wind, or acid rain. ${ }^{40}$ Climatic conditions of the two selected sites for this study are quite different so it is expected to be one of the causes of morphological differences. Ushuaia leaves had thicker cuticle probably for the most extreme weather conditions that plants undergo. On the other hand, Ushuaia site has a greater intensity of visible and UV light and this factor is positively correlated with the enlargement of cuticle thickness to create a lotus effect to reflect UV radiation and integration of protective flavonoid compounds in the cuticle. These results are in agreement with Davi et al. ${ }^{23}$ who determined that plants grown in high light generally have thick leaves caused by extra layers of palisade mesophyll or longer palisade cells to protect them from high-light damage.

Different appearance between the abaxial epidermis could be due to Moreno leaves were still growing while Ushuaia leaves growth had ceased. In effect, surface wax appears to be deposited only on young leaves, and essentially only during or shortly after the period of leaf expansion. Wax deposition is probably related to the development and solidification of the cuticular layer. ${ }^{44}$

The structural basis of cuticle is a combination of surface roughness in the micrometer range combined with a strong hydrophobicity caused by superimposed wax sculptures (epicuticular waxes) in the nanometer range. ${ }^{45}$ Epicuticular waxes strongly influence the wet ability, self-cleaning behavior and the light reflection at the cuticle interface. ${ }^{46}$ It is remarkable that particularly secondary alcohols as nonacosane-10-ol among others induce non-planar structures such as tubules and other irregular forms. ${ }^{45}$ Waxes are solid, but their structures reveal analogies to those of liquid crystals. The formation of a layer structure may be inhibited by a strong variation in the chain length of the molecules or by a missing positional order, causing a nematic structure with a two-dimensional order. For the other hand, wax synthesis and extraction stopped when cell expansion ceased. ${ }^{47}$
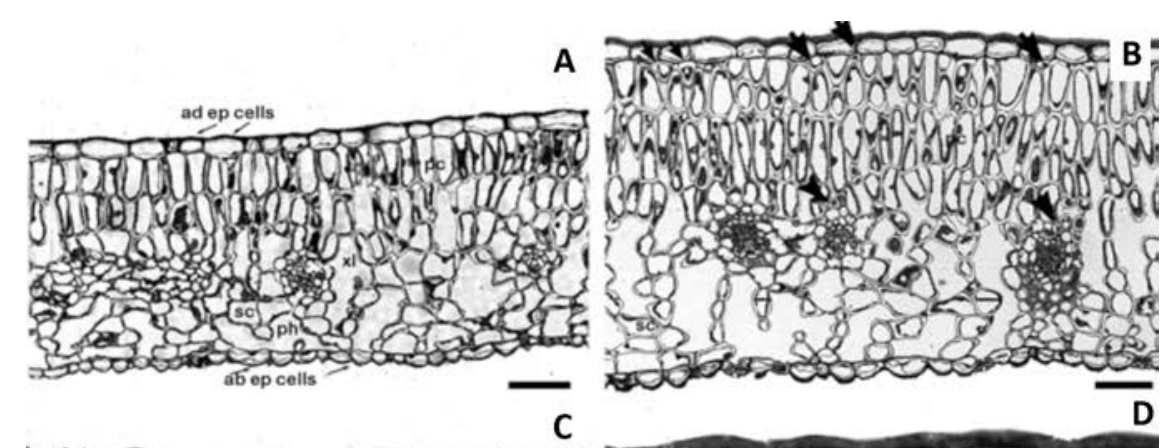

然
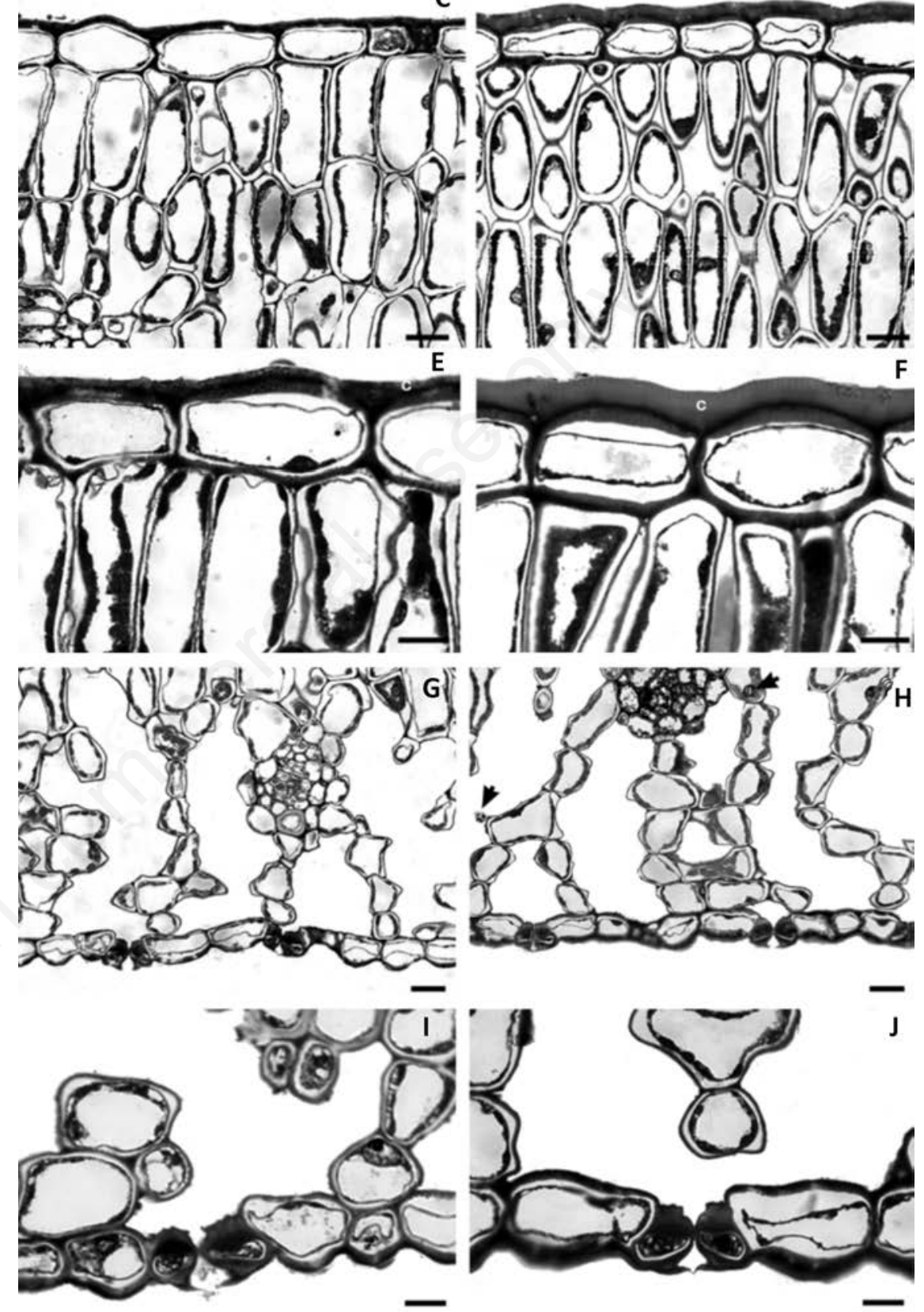

Figure 2. Micrograph of cross-section of Berberis microphylla leaves collected on Moreno (A,C,E) and Ushuaia sites (B, D, F). A-B, view of total cross-section leaf with adaxial epidermal cells (ad ep cells), abaxial epidermal cells (ab ep cells), palisade mesophyll cells (pc), spongy mesophyll cells (sc), phloem cells (ph), xylem cells (xl) and sclerenchyma cells (arrowhead); C-D, Detail of adaxial epidermal and palisade mesophyll tissues; E-F, Detail of abaxial epidermal cells and cuticle (c). Bars: A-B, $100 \mu \mathrm{m} ; \mathrm{C}-\mathrm{D}, 25 \mu \mathrm{m} ; \mathrm{E}-\mathrm{F}, 10$ $\mu \mathrm{m}$. G-J) Detail of the palisade mesophyll tissue and the stomata of abaxial epidermal of Berberis microphylla leaves collected on Moreno (G,I) and Ushuaia sites (H,J). Bars: G-I, $25 \mu \mathrm{m} ; \mathrm{H}-\mathrm{J}, 10 \mu \mathrm{m}$. 

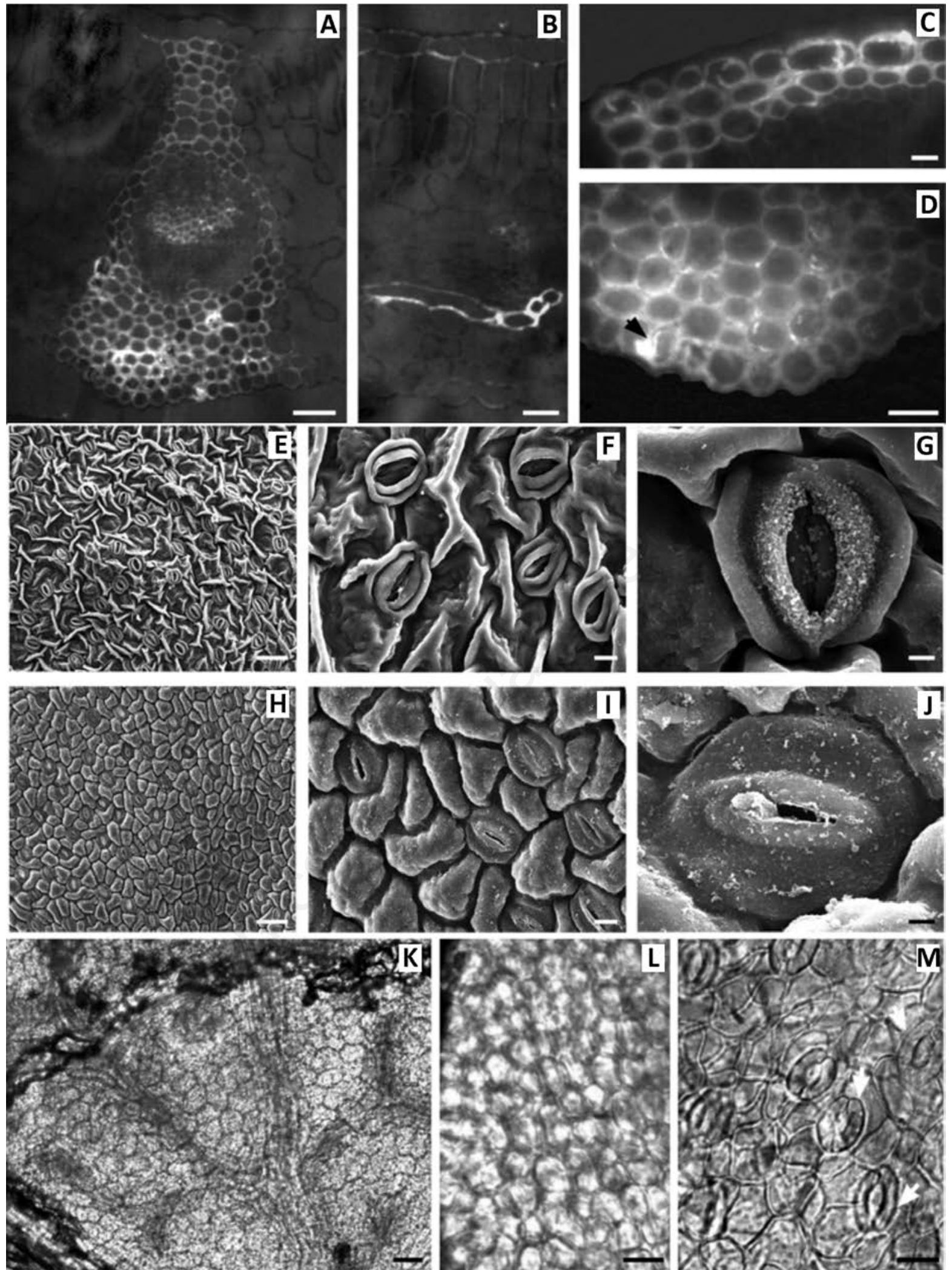

Figure 3. A-D) Micrograph of cross-section of Berberis microphylla leaves observed by UV filter BP 340-380. A) View of central vascular bundle and parenchyma cells with fluorescence; B) transversal vascular bundle with fluorescence; C) epidermal and sclerenchyma cells on the leaf apex with fluorescence; D) detail of stomata (arrowhead) and laticifer-idioblast cells. Bars: A-B, $10 \mu \mathrm{m} ; \mathrm{C}, 25 \mu \mathrm{m} ; \mathrm{D}, 5 \mu \mathrm{m}$. E-J) SEM micrograph of abaxial epidermis of Berberis microphylla leaves collected on Moreno (E-G) and Ushuaia site (H-J). E,H) General view; F,I) detail of surface of abaxial epidermis tissue; G,J) stomata detail. Bars: E,H, $50 \mu \mathrm{m} ; \mathrm{F}, \mathrm{I}, 10 \mu \mathrm{m} ; \mathrm{G}, \mathrm{J}, 5000 \mathrm{~nm}$. K-M) Micrograph of diaphanized Berberis microphylla leaves. K, leaf venation; L, Detail of adaxial epidermal cells; L, Detail of abaxial epidermal cells with stomata (arrows). Bars: 2 $\mu \mathrm{m}$. 
Flavonoid compounds usually accumulate in the central vacuoles of guard cells and epidermal cells as well as subepidermal cells of leaves. ${ }^{48}$ Several classes of phenolic compounds are strongly autofluorescent when irradiated with UV or blue light. Therefore, fluorescence microscopy is a powerful tool for studying tissue localization of these metabolites. ${ }^{49}$ Berberine is a quaternary ammonium salt from the pro toberberine group of isoquinoline alkaloids that possess low fluorescence emission in an aqueous solution ${ }^{50}$ and it is well known that berberine stain a bright yellow. ${ }^{6}$ This property would explain the intense yellow color of diaphanized leaves (data not shown).

\section{Conclusions}

Plant plasticity is an advantageous strategy for survival in changing environmental conditions, being leaves photosynthetic organs thus their shapes, sizes and structure are important factors influencing the success of the plants. $B$. microphylla leaves showed a high phenotypic plasticity between the two sites of cultivation. The changes in the leaf morphology and structure observed in Moreno leaves could indicate that the plants are trying to adjust its morphology to the new culture conditions i.e. higher temperatures and lower irradiance. The correlation of the observed changes together with the plasticity on the leaf physiology, the nutrient and pigment contents will be of interest to study, as well as with the reproductive performance to apply on future genetic improvement.

\section{References}

1. Hogan CM, WWF. Magellanic subpolar forests. 2014. Available from: http://www. eoearth.org/view/article/154355/

2. Moore DM. Flora of Tierra del Fuego. Oswestry: Anthony Nelson \& Missouri Botanical Garden; 1983.

3. Lencinas MV, Martínez Pastur G, Rivero P, Busso C. Conservation value of timber quality versus associated non-timber quality stands for understory diversity in Nothofagus forests. Biodivers Conserv 2008;17:2579-97.

4. Shaffer JE. Inotropic and chronotropic activity of berberine on isolated Guinea pig Atria. J Cardiovasc Pharmacol 1985;7:307-15.

5. Orsi MC. Berberidaceae. In: Correa MN, ed. Flora Patagónica. Buenos Aires: INTA; 1984. pp 325-48.

6. Fajardo Morales V, Podestá F, Urzúa A.
Reseña de los alcaloides encontrados en el género Berberisde Chile. Rev Latinoamer Quím 1986;16:141-56.

7. Fajardo Morales V. Estudio químico de las especies chilenas del género Berberis. Rev Latinoamer Quím 1987;18:46-50.

8. Mokhber-Dezfuli N, Saeidnia S, Reza Gohari A, Kurepaz-Mahmoodabadi M. Phytochemistry and pharmacology of berberis species. Pharmacogn Rev 2014;8:8-15.

9. Pomilio AB. Anthocyanins in fruits of Berberis buxifolia. Phytochem 1973;12: 218-20.

10. Medrano MA, Tomas MA, Frontera MA. Isolation and identification of anthocyanins in fruits from Chubut Province (Argentina). Fruits of Ribes aureum Pursh, R. magellanicum Poir and Berberis darwinii Hook. Rev Latinoamer Quim 1985;16 84-6.

11. Motalleb G, Hanachi P, Kua SH, et al. Evaluation of phenolic content and total antioxidant activity in Berberis vulgaris fruit extract. J Biol Sci 2005;5:648-53.

12. Arena ME, Curvetto N. Berberis buxifolia fruiting: kinetic growth behavior and evolution of chemical properties during the fruiting period and different growing seasons. Sci Hortic 2008;11:120-7.

13. Ruiz A, Hermosin-Gutierrez I, Mardones C, et al. Polyphenols and antioxidant activity of calafate (Berberis microphylla) fruits and other native berries from southern Chile. J Agric Food Chem 2010;58:6081-9.

14. Koncic MZ, Kremer D, Karlovic K, Kosalec I. Evaluation of antioxidant activities and phenolic content of Berberis vulgaris L. and Berberis croatica Horvat. Food Chem Toxic 2010;48:2176-80.

15. Surveswaran D, Cai YZ, Corke H, Sun M. Systematic evaluation of natural phenolic antioxidants from 133 Indian medicinal plants. Food Chem 2007;102:938-53.

16. Tomosaka H, Chin YW, Salim AA, et al. Antioxidant and cytoprotective compounds from Berberis vulgaris (barberry). Phytother Res 2008;22:979-81.

17. Arena ME, Vater G, Peri P. Fruit production of Berberis buxifolia Lam in Tierra del Fuego. Hort Sci 2003;38:200-2.

18. Arena ME, Giordani E, Radice S. Phenological growth and development stages of the native Patagonian fruit species Berberis buxifolia Lam. JFAE 2013;11:1323-7.

19. Arena ME, Postemsky P, Curvetto NR. Accumulation patterns of phenolic compounds during fruit growth and ripening of Berberis buxifolia, a native Patagonian species. New Zeal J Bot 2012;50:15-28.

20. Arena ME, Zuleta A, Dyner L, et al. Berberis buxifolia fruit growth and ripening: evolution in carbohydrate and organic acid contents. Sci Hortic 2013;158:52-8.

21. Arena ME, Giordani E, Radice S. Flowering, fruiting and leaf and seed variability in Berberis buxifolia, a native Patagonian fruit species. In: Marin L, Kovac D. Native species: identification, conservation and restoration. New York: Nova Sciences Publishers; 2011.

22. Arena ME, Radice S. Shoot growth and development of Berberis buxifolia Lam. in Tierra del Fuego (Patagonia). Sci Hortic 2014;165:5-12.

23. Davi H, Barbaroux C, Dufrêne E, et al. Modelling leaf mass per area in forest canopy as affected by prevailing radiation conditions. Ecol Model 2008;211:339-49.

24. Guo WH, Li B, Zhang XS, Wang R. Architectural plasticity and growth responses of Hippophaerhamnoides and Caragana intermedia seedlings to simulated water stress. J Arid Environ 2007;69:385-99.

25. Arambarri AM, Freire SE, Colares MN, et al. Leaf anatomy of Medicinal Shrubs and Trees from Gallery Forests of the Paranaense Province (Argentina). Part 1. Bol Soc Argent Bot 2006;41:233-68.

26. Tamiselvi S, Balasubramani SP, Venkatasubramanian P, Vasanthi NS. A review of the pharmacognosy and pharmacology of the herbals traded as Daruharidra. Int $\mathrm{J}$ Pharm Biol Sci 2014;5:556-70.

27. Upadhyay GC, Bhatkoti M, Bhatt NN, et al. A comparative study of Berberis aristata D.C. and Berberis asiatica Roxb.ex. D.C. (Daruharidra) W.S.R to Madhumehahara Karma. Int J Pharm Biol Arch 2012;3:4727.

28. Henderson GA, Hay GW. The carbohydrates of the leaves of common barberry (Berberis vulgaris). The extraction, fractionation and structural studies of selected non-cellulosic polysaccharides. Carbohydr Res 1972;23:379-98.

29. Freire SE, Arambarri AM, Bayón ND, et al. Epidermal characteristics of toxicplants for cattle from the Salado River Basin (Buenos Aires, Argentina). Bol Soc Argent Bot 2005;40:241-81.

30. Komal S, Ranjan B, Neelan C, et al. Berberis aristata. A review. IJRAP 2011;2:383-8.

31. Rathi B, Sahu J, Koul S, Khosa RL. Salient features of Berberis aristata and Berberis asiatica: A comparative pharmacognostical study. Der Pharmacia Lettre 2013;5:40-2.

32. Sabir S, Tahir K, Rashid N, et al. Phytochemical and antioxidant studies of Berberis lycium. Pak J Pharm Sci 2013;26:1165-72.

33. Wu H, Zhang L, Du L. Ionic liquid sensitized fluorescence determination of four isoquinoline alkaloids. Talanta 
2011;85:787-93.

34. Atkin OK, Loveys BR, Atkinson LJ, Pons TL. Phenotypic plasticity and growth temperature: understanding interspecific variability. J Exp Bot 2006;57:267-81.

35. Tognetti R, Minotta G, Pinzauti S, et al. Acclimation to changing light conditions of long-term shade-grown beech (Fagus sylvatica) seedlings of different geographic origins. Trees 1998;12:326-33.

36. Casal JJ. Shade avoidance. The Arabidopsis Book 2012;10:e0157.

37. Niinemets Ü, Cescatti A, Christian R. Constraints on light interception efficiency due to shoot architecture in broadleaved Nothofagus species. Tree Physiol 2004;24:617-30.

38. Tsukaya H. Leaf shape: genetic controls and environmental factors. Int J Dev Biol 2005;49:547-55.

39. Pollard M, Beisson F, Li Y, Ohlrogge JB. Building lipid barriers: biosynthesis of cutin and suberin. Trends Plant Sci 2008;13:236-46.

40. Barthlott W, Neinhuis C, Cutler D, et al.
Classification and terminology of plant epicuticular waxes. Bot J Linnean Soc 1998;126:237-60.

41. McFarlane HE, Watanabe Y, Yang W, et al. Golgi- and trans-golgi network-mediated vesicle trafficking is required for wax secretion from epidermal cells. Plant Physiol 2014;164:1250-60.

42. Buschhaus C, Jetter R. Composition differences between epicuticular and intracuticular wax substructures: how do plants seal their epidermal surfaces? J Exp Bot 2011;62:841-53.

43. De Bono A, Yeats TH, Rose JKC, et al. Arabidopsis LTPG is a glycosyl phosphatidylinositol-anchored lipid transfer protein required for export of lipids to the plant surface. Plant Cell 2009;21:1230-8.

44. Schieferstein RH, Loomis WE. Development of the cuticular layer in angiosperm leaves. Amer $\mathrm{J}$ Bot 1959;46:625-35.

45. Koch K, Ensikat HJ. The hydrophobic coatings of plant surfaces: epicuticular wax crystals and their morphologies, crys- tallinity and molecular self-assembly. Micron 2008;39:759-72.

46. Bargel H, Koch K, Cerman Z, Neinhuis C. Structure-function relationships of the plant cuticle and cuticular waxes: a smart material? Funct Plant Biol 2006;3:893-910.

47. Giese BN. Effects of light and temperature on the composition of epicuticular wax of barley leaves. Phytochem 1975;14:921-8.

48. Weissenböck G, Hedrich R, Sachs H. Secondary phenolic products in isolated guard cell, epidermal cell and mesophyll cell protoplasts: distribution and determination. Protoplasma 1986;134:141-8.

49. Hutzler P, Fischbach R, Heller W, et al. Tissue localisation of phenolic compounds in plants by confocal laser scanning microscopy. J Exp Bot 1998;49:953-65.

50. Xu F, Gou W, Xu W, et al. Leaf morphology correlates with water and light availability: what consequences for simple and compound leaves? Prog Nat Sci 2009;19:178998. 